\title{
The role of nurses in the prevention of metabolic syndrome in spa environment
}

\author{
St. Elizabeth University of Health and Social Sciences, Bratislava, Slovakia \\ veronikape76@centrum.sk,mriab9@gmail.com
}

\author{
Петрекова В., Беловічкова М. \\ Роль медичних сестер в профілактиці \\ метаболічного синдрому в умовах курорту \\ Вища школа охорони здоров'я та соціальної роботи \\ Св. Алжбети, м. Братислава, Словаччина
}

\author{
Петрекова В., Беловичкова М. \\ Роль медсестер в профилактике \\ метаболического синдрома в условиях курорта \\ Высшая школа здравоохранения и социальной работы \\ Св. Елизаветы, г. Братислава, Словакия
}

\section{Introduction}

Metabolic syndrome is currently becoming one of the most common diseases in the world. It is defined as a nonrandom co-occurrence of metabolic disorders associated with arterial hypertension, type 2 diabetes mellitus/impaired glucose tolerance, insulin resistance, elevated blood triaglycerol levels, atherogenic dyslipidemia, central obesity in combination with other influenceable but also uninfluenceable risk factors that support the risk of developing other serious diseases. [1,2]. It belongs to the diseases of civilization. Metabolic syndrome affects more than $30 \%$ of the adult population in North America and Europe [1]. Recent multicenter screening study "The prevalence of diabetes mellitus and metabolic syndrome in Slovakia" confirmed that about $20 \%$ of the Slovak population meets the criteria for metabolic syndrome. What is striking is the increased incidence of obesity even in adolescents and younger adults, which is likely to be reflected in an increase in the incidence of metabolic syndrome in the future" [3].

Currently we have knowledge of the epidemiology and pathophysiology of this disease, the treatment options for all components of the metabolic syndrome. Unfortunately, the term metabolic syndrome is not well known among patients.

\section{Survey methods}

When processing the work, we used a questionnaire of our own design, which was anonymous and which we distributed to patients in the Vyšné Ružbachy Spa. Completion of the questionnaire was on a voluntary basis. In the questionnaire, we focused on the patients awareness of the metabolic syndrome disease. The questionnaire consisted of 23 questions. The questions were ordered from simple questions such as patient's gender, age, education, BMI (body mass index) or blood pressure (BP) value, to more complex questions (questions about daily activities, consumption of vegetables or fruits, sports activities, information about the types of diseases the patient is being treated for). In the questionnaire we wanted the patients to comment on the metabolic syndrome itself. We asked if they were familiar with the term metabolic syndrome, if they had any information about this disease, if they knew what diseases cause the metabolic syndrome.

\section{Characteristics of the survey sample}

The survey sample consisted of patients in the Vyšné Ružbachy Spa. The survey file was composed of 100 respondents, consisting of men (49) and women (51) of various ages and education. The average age of the respondents was 40 years. The most frequent age group involved in completing the questionnaire was between 31 and 50 years.

\section{Survey hypotheses}

H1: Patients with higher education will have better knowledge about the values of their BMI and BP

$\mathrm{H} 2$ : Patients with higher education will have better knowledge on the metabolic syndrome and its classification as a disease of civilization

H3: Patients with higher education are more engaged in physical activities.

H4: Healthy diet will be more frequently maintained in female patients.

H5: Treatment options for metabolic syndrome will be more familiar to respondents with higher education

H6: Patients of higher age will have better knowledge on the metabolic syndrome and its classification as a disease of civilization

H7: Awareness of the risk of metabolic syndrome is greater in polymorbid patients

\section{Results analysis}

Due to the limited number of pages in the publication, we decided to summarize the analysis of the results in a discussion. In the analysis of the results, we placed 3 graphs important for our work, which were created on the basis of the respondents' answers. 


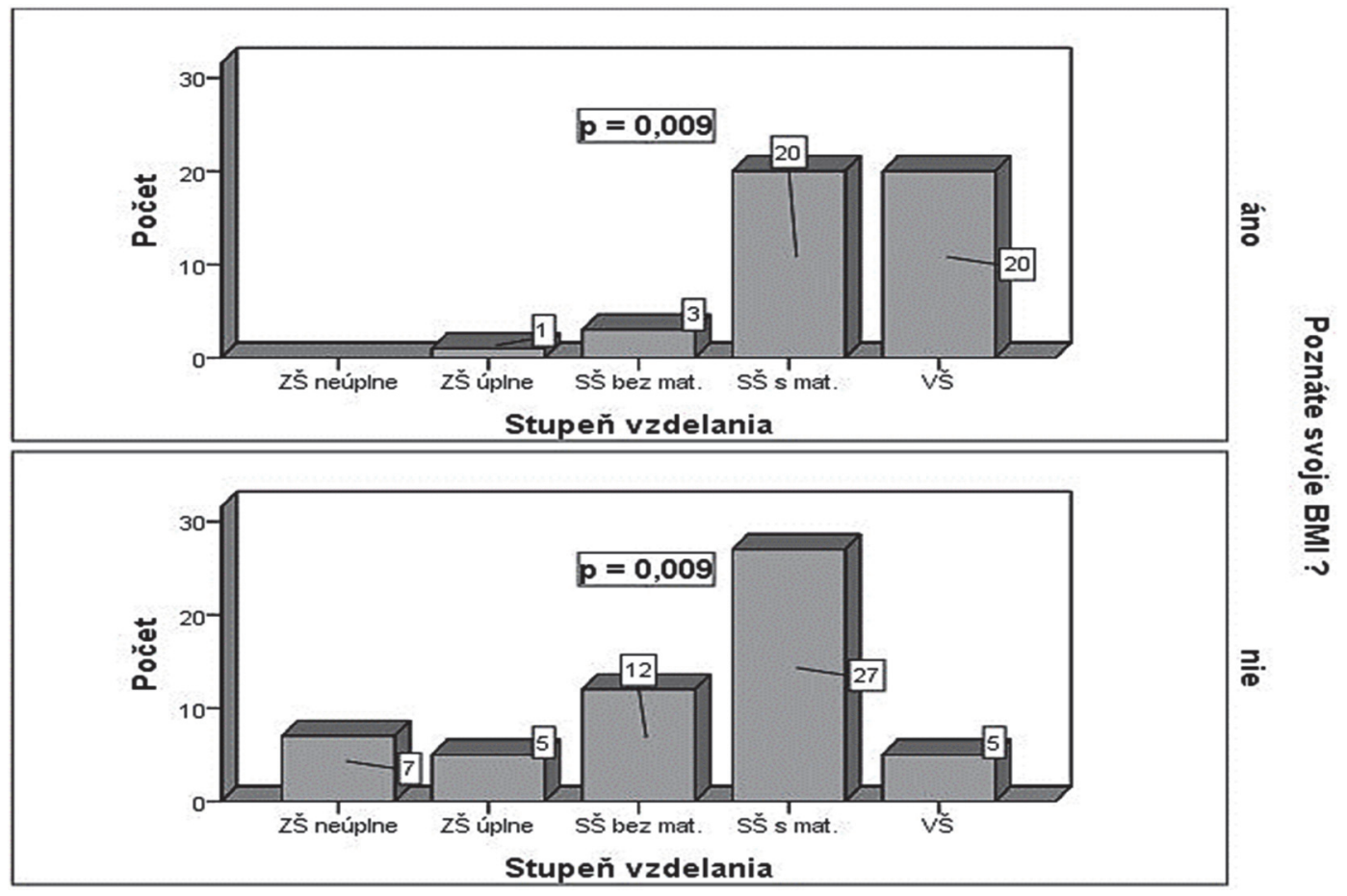

Fig. 1. Knowledge of BMI in women and men by the level of their education
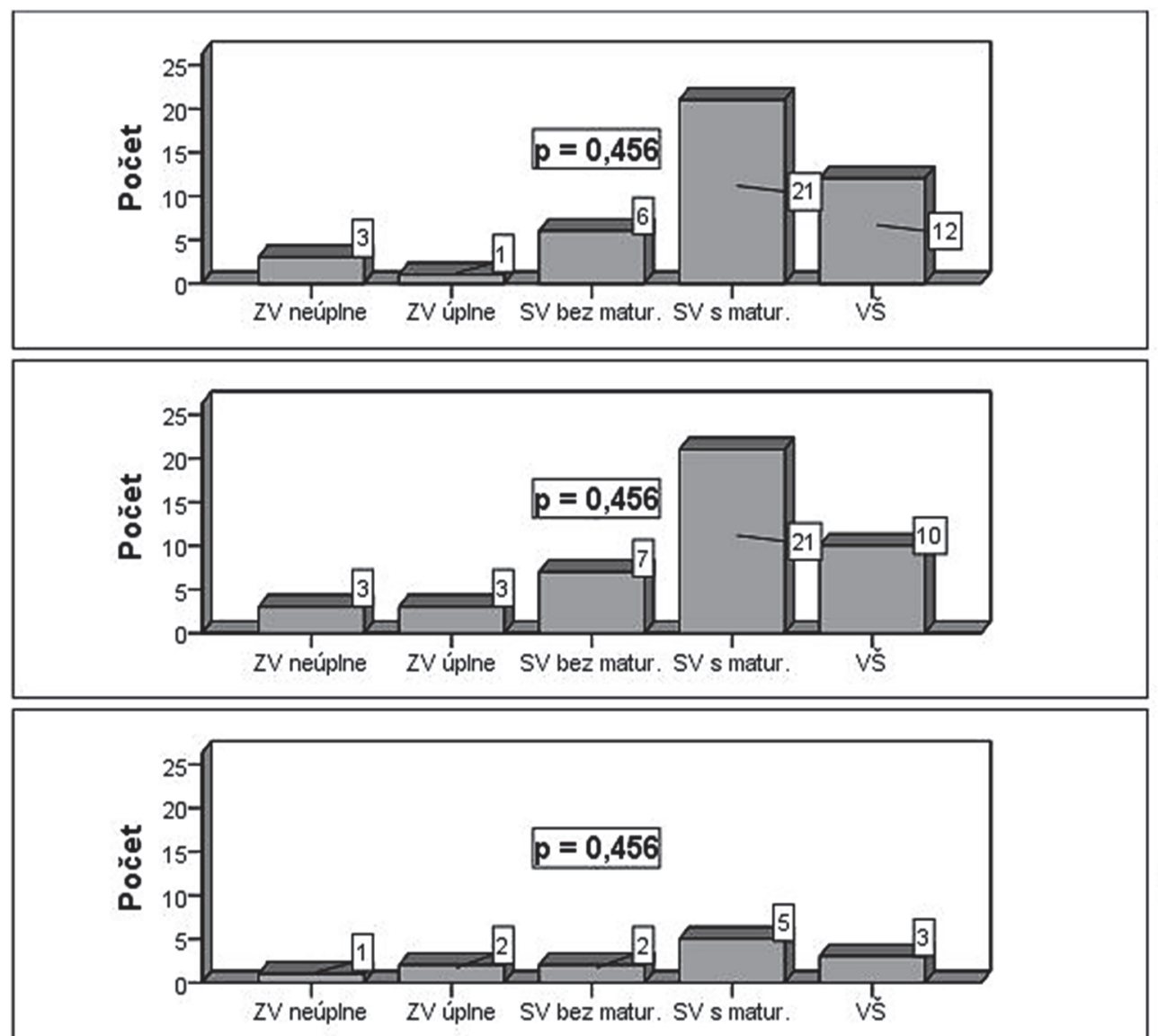

รั่

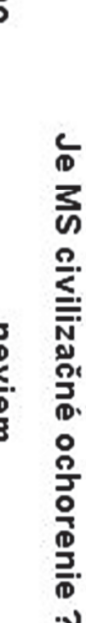

ㄱ.

Fig. 2. Comparison of responses to the question: „Is metabolic syndrome a disease of civilization?“ with respect to respondents' education 


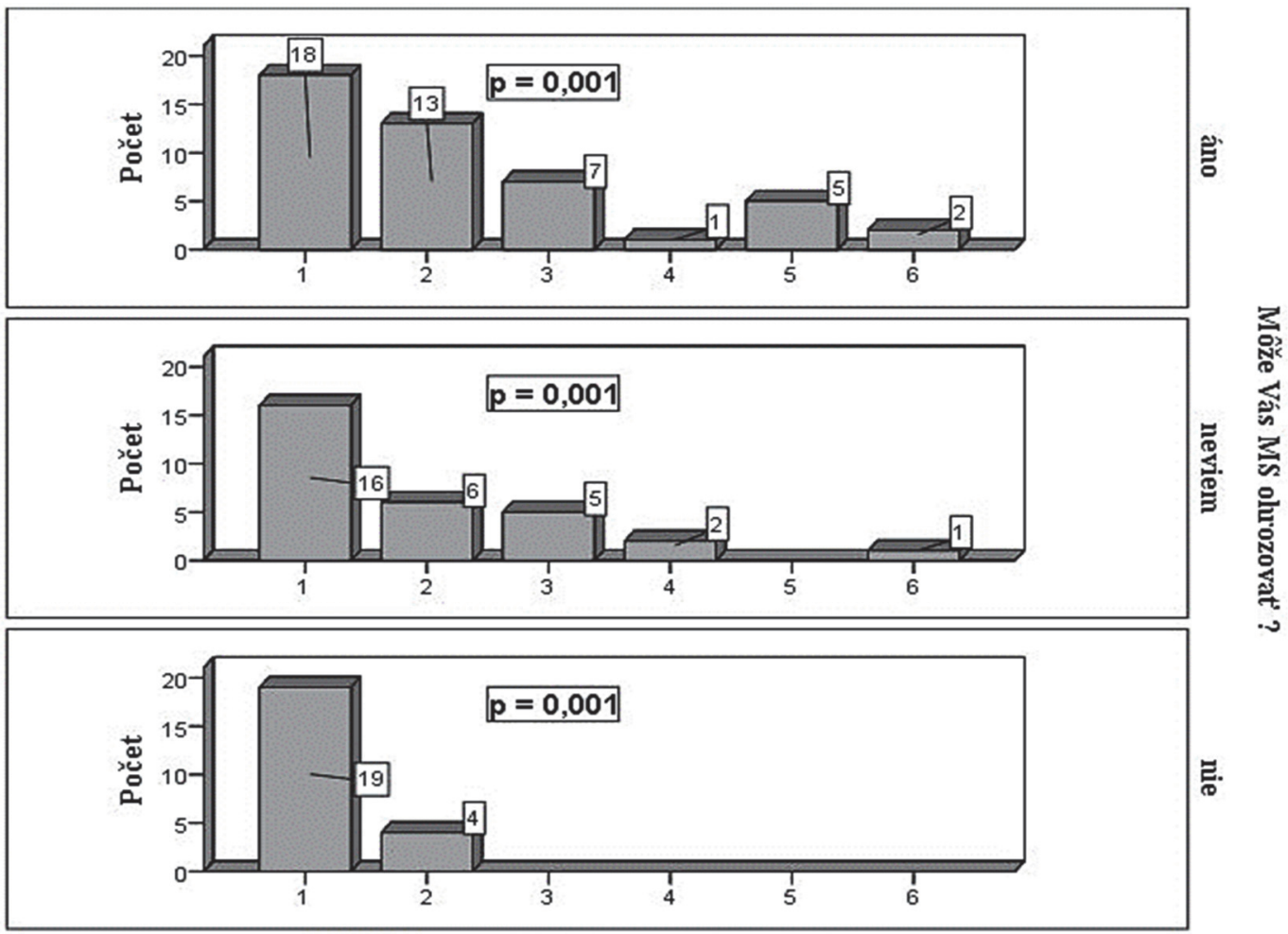

Fig. 3. Are you at risk of metabolic syndrome?

Explanation: Počet - number; Stupeň vzdelania - level of education; ZŠ/ZV neúplné - incomplete elementary,

ZŠS/ZV complete - complete elementary, ŠS/SV bez mat. - secondary school without school leaving examination, S ̌S/SV s mat. - secondary school with school leaving examination, VŠ - university; áno - yes, neviem - I do not know, nie - no

We can see that most respondents are aware of the threat of metabolic syndrome, regardless of age, education, disease.

\section{Discussion}

Most risk factors for diseases of civilization can be influenced by ones lifestyle. Improper diet, physical inactivity, smoking and alcohol abuse cause more than $80 \%$ of the most common chronic diseases [4]. Patients with metabolic syndrome have been shown to be at increased risk of developing diabetes, cardiovascular disease, but also of sudden death [5].

In our work, we intended to point out the importance of nursing in the prevention of this serious disease of civilization and present the results of our research. In this work, we set 7 hypotheses, which we verified through our questionnaire.

In hypothesis H1, we evaluated the knowledge on BMI and BP in patients with higher education. $56 \%$ of the respondents we contacted stated that they were not able to calculate their BMI. According to our results, most respondents are either overweight or obese and are unable to judge for themselves whether they are overweight or obese. $\mathrm{H} 1$ has been confirmed - patients with higher education have a higher level of knowledge about their health condition. They often have: less physically demanding work, time to focus on their health and time for education in a certain area. They can for example devote to maintaining healthy lifestyle.

Under the term "lifestyle" we can understand rather stable life activities that reflect the value orientation of a person, their relationship to life, work, society, their interests and hobbies, what they consider important and what they find some satisfaction in. One is focused on the best way to live, what to dedicate their lives to, how to fulfil it. They prefer activities that they consider useful or necessary, as well as those that bring them pleasure. However, at the same time, pleasant does not have to be beneficial and vice versa. Many of the components of life style (compliance to personal hygiene, proper nutrition, adequate workload and plenty of rest, physical activity, moderate alcohol consumption) are closely related to the maintenance and development of health, or to the formation and development of diseases [6].

Hypothesis H2: Patients with higher education will have better knowledge on the metabolic syndrome and its classification as a disease of civilization. Our statement for this hypothesis was confirmed by the answers for question Are you familiar with the metabolic syndrome?

Hypothesis $\mathrm{H} 3$ concerned physical activity: Patients with higher education are more engaged in physical activities. Hypothesis $\mathrm{H} 4$ concerned rational diet: Healthy diet will be more frequently maintained in female patients. Both hypotheses were confirmed. We can say with certainty that according to the evaluated answers, patients with higher education pay more attention to physical leisure activities and sports, either active or recreational ones. Patients with higher education are more likely to eat healthy compared to patients with other types of education. Women eat healthier than men, their diet is more varied. It consists of more vegetables and 
fruits compared to men's diets, in which, on the contrary, we may find more frequent consumption of meat dishes.

The main principles of rational nutrition include, for example, moderate eating, the principle of balanced nutrition, dividing the number of meals into 3 to 5 servings, variety of the diet, intake of eatables or fluid intake [6]. Temperance is said to be a forgotten virtue. Therefore, it is necessary to talk about temperance, as virtue is a constant act of will that leads us to do good for our health [7]. The body needs building, energy, protective and supplementary substances. Food must be health harmless and have the necessary biological value [6].

In our current diet, we record an overall low intake of fibre and a long-term low intake of protective antioxidants, which are found in fruits, vegetables, mushrooms and other sources. Antioxidants protect the body against free radicals. Free radicals interact with UV damage to the skin, damage organs and cause damage at the cellular level. They also play an important role in the development of chronic noncommunicable diseases $[6,8,9]$.

Hypothesis $\mathrm{H5}$ spoke about treatment options for metabolic syndrome, which will be more familiar to respondents with higher education. From the evaluations of the answers to the questions "Are you familiar with the treatment options for MS" and "Do you want to know more about MS", we found that although some of the patients in our study sample did not know about all the options for treating the metabolic syndrome, they answered correctly: a healthy, balanced diet, exercise, psychohygiene. In general, however, we must confirm that, although a small number of patients managed to answer this question correctly, patients with a university degree were most successful in it.

Therapeutic approaches in patients with metabolic syndrome present several options such as diet therapy, physical activity, pharmacotherapy, cognitive-behavioural therapy (CBT), surgical treatment and spa treatment [10]. CBT represents one of the basic directions of contemporary psychotherapy. It is based on the assumption that inappropriate habits (eating and exercise) are learned and by the same mechanisms as they were acquired, they can also be unlearned using psychological methods [11].

Usually a combination of several methods is used. The treatment of the metabolic syndrome with all its complications is a long-term process that requires great determination, selfdenial and patience of the patient. The treatment of a patient with metabolic syndrome must be comprehensive and multidisciplinary, as the goal of therapy is not only to reduce weight, but also to gradually eliminate all complications and prevent the emergence of additional risks [12].

When asked if patients wanted to know more about the metabolic syndrome, the answer "yes" was more often pronounced among respondents with higher education. It can be said that $\mathrm{H} 5$ has been confirmed.

We are convinced that nurse should be actively involved in the educational process of patients, their task being not only gaining patient's trust, but also reducing patient's fear of the unknown.

Education can be described as a process that helps people acquire healthy behaviours in their daily lives, strengthens patient's competencies and self-confidence, and develops their self-care skills [13]. Education is essential and important in treatment and can not only reduce the risk of late complications and economic consequences, but also help the patient to lead a quality life and live to old age [14].

Education plays an important role in achieving changes in the behaviour of patients with metabolic syndrome. The implementation of education takes place in the form of an educational process, which represents the systematic, logical, subsequent and planned activities of the educator (nurse, doctor) and of the educatee (patient, family, community). The actual implementation of education can be performed in either, individual or group form [15].

Hypothesis $\mathrm{H6}$ concerned the awareness of that knowledge about the metabolic syndrome and its classification as a disease of civilization will be better in patients of higher age. Patients' knowledge has been shown to be age-independent, so increasing health literacy is certainly useful and necessary throughout the population, not just in selected age groups. We hereby conclude that hypothesis H6 was not confirmed.

The latest hypothesis $\mathrm{H} 7$ states that awareness of the risk of MS is greater in polymorbid patients. The hypothesis has been confirmed. According to the answers in the processed questionnaires, patients with a higher number of diagnoses are more aware of the risk of MS. For effective education of these patients it is possible to use various teaching aids, e.g. educational sheets, posters, whiteboards, audio recordings and others. Education is one of the important competencies and responsibilities of health professionals [15].

\section{Conclusions}

Based on our findings, we believe that it is important to repeatedly point out to patients the importance of preventing the metabolic syndrome and the diseases that create the metabolic syndrome. "Patients have the right to know about their state of health, as well as about the diseases that may threaten them, about their diagnosis, its course, complications and treatment options" [16].

When processing the data from the questionnaire, we found out that more than half of the respondents are willing to obtain information about the metabolic syndrome through an educational lecture or educational materials.

Indeed, education presents one of the nonpharmacological ways of influencing the patient and their families in the context of secondary prevention and forms an important part of the overall treatment of the patient [17]. It is a process that influences their behaviour and actions. It enables us to make changes in the knowledge, attitudes and skills needed to promote, protect and develop patients' health. It is an important part of all nursing activities [12]. The most important meaning of education in the prevention of diseases of civilization is that the effect of treatment is long-lasting and significant and that the patient is sufficiently motivated to change their lifestyle and especially that their disease does not progress to chronicity, disability or mortality $[18,19]$.

We are convinced that in the education of patients about the issue of metabolic syndrome, the nurse has an irreplaceable place not only in the hospital but also in the outpatient sphere and in the environment of spas. 


\section{References}

1. Svačina, Š. et al. 2006. Metabolic syndrome. 3rd extended edition. Prague: Triton, $2006.282 \mathrm{p}$. ISBN 978-80-7254-782-8.

2. Krahulec, B., Fábryová, L., Holéczy, P., Klimeš, I. Et al. 2013. Clinical obesitology. 1st edition. Brno: Facta Medica, 2013. 336 p. ISBN 978-80-904731-7-1.

3. Lenhartová, D. 2014. Metabolic syndrome and blood vessels. Diploma thesis. Bratislava: Comenius University in Bratislava LF, 2014. 54p.

4. Bražinová, A. 2019. Occurrence of risk factors of diseases of civilization in clients of health counseling in the Slovak Republic in the period 1993-2017. P. 24-25. In: Proceedings VI. from International Scientific Conference: Health, Social and Nursing Aspects of Diseases of Civilization 15.11.2019. VŠZaSP sv. Alžbety Bratislava, ISBN 978-80-8132-207-5.

5. Nováková, B. 2019. Prokinetics in the treatment of patients with metabolic syndrome. P. 51. In: Proceedings of abstracts VI. from International Scientific Conference: Health, Social and Nursing Aspects of Diseases of Civilization 15.11.2019. VŠZaSP sv. Alžbety Bratislava, ISBN 978-80-8132-207-5.

6. Kimáková, T., Issa, M., Nasser, B., Uher, I., Schuster, J. 2020. Selected aspects of lifestyle in the prevention of chronic non-communicable diseases. P. 156-160. In.: Proceedings VI. from International Scientific Conference: Health, Social and Nursing Aspects of Diseases of Civilization 15.11.2019. Collegium Humanum, Warsaw 2020,209 p. ISBN: 978-83-952951-3-3.

7. Vansáč, P. 2018. Moderate diet as a prevention of obesity. P. 365-372. In: Proceedings from the Days of practical obesitology and metabolic syndrome 21-22.06.2018. Department of Philosophy, Department of Psychology, University of Finance and Management in Warsaw, Warsaw 2018, 388 p. ISBN 83-89884-07-0.

8. Kimáková, T., Pavlík, V. 2017. Antioxidants and their importance in the prevention of chronic diseases. Košice: Pavel Jozef Šafárik University in Košice, 2017. 153 p. ISBN 978-80-8152-513-1.

9. Belovičová, M., Vansáč, P. 2019. Selected aspects of medical and social care for long-term ill persons. Towarzystwo Slowaków w Polsce, Kraków, 2019, 153 p. ISBN 978-83-811110-9-6.

10. Belovičová, M. 2019. Physiotherapy as a part of a complex non-pharmacological treatment of obesity in medical spa enviroment. I науково-практична конференція 3 міжнародною участю, присвячена 20-й річниці 3 дня заснування факультету здоров’я та фізичного виховання. «Сучасні підходи до формування професійних компетентностей фахівців фізичної терапії та ерготерапії» 17-18.10.2019 Užhorod. Ukrajina. Zdorovja nacii. 2019; 55(2): 146-147. ISSN $2077-6594$.

11. Málková, I. 2020. Possibilities of using STOBU activities in the practice of doctors and nutrition therapists. P. 185-192. In.: Proceedings VI. from International Scientific Conference: Health, Social and Nursing Aspects of Diseases of Civilization 15.11.2019. Collegium Humanum, Warsaw 2020, 209 p. ISBN 978-83-952951-3-3.

12. Hudáková, T., Popovičová, M. 2020. Extremely obese patient in the intensive care unit in terms of nursing approach. p. 117-124. In : Proceedings VI. from International Scientific Conference: Health, Social and Nursing Aspects of Diseases of Civilization 15.11.2019. Collegium Humanum, Warszawa 2020, 209 p. ISBN 978-83-952951-3-3.

13. Nemcová, J. Et al. 2010. Modern education in nursing. Martin: Osveta, 2010. 259 p. ISBN 978-80-8063-321-9.

14. Popovičová, M., Kovácsová, B. 2016. The importance of fasting and postprandial glycemia in the prevention of diabetic retinopathy. In Florence. Praha: Ambit Media, a. s., ISSN 1801-464X, 2016, roč. 7, č. 11., s. 18-22.

15. Dimunová, L. Raková, J. 2018. Education as a part of secondary prevention of obesity. P. 65-71. In: Proceedings from the Days of practical obesitology and metabolic syndrome 21-22.06.2018. Department of Philosophy, Department of Psychology, University of Finance and Management in Warsaw, Warsaw 2018, 388 p. ISBN 83-89884-07-0.

16. Lauková, J., Melichová, A., Turáneková, Z. 2020. Management of nursing care for patients with metabolic syndrome. Nursing and midwifery, 2020, no.1, p.30. ISSN 1339-5920.

17. Dimunová, L., Raková, J., Zamboriová, M. et al. 2019. Modern education as a tool of secondary cardiovascular prevention. p.33. In: Proceedings of abstracts VI. from International Scientific Conference: Health, Social and Nursing Aspects of Diseases of Civilization 15.11.2019. VŠZaSP sv. Alžbety Bratislava, ISBN 978-80-8132-207-5.

18. Raková, J., Sušinková, J., Dimunová, L., Kurcinová, H. 2019. A new look at the educational work of a nurse in a child with overweight and obesity. p. 65. In: Proceedings of abstracts VI. from International Scientific Conference: Health, Social and Nursing Aspects of Diseases of Civilization 15.11.2019. VŠZaSP sv. Alžbety Bratislava, ISBN 978-80-8132-207-5.

19. Babečka, J. 2019 Nursing education for patients with diabetes mellitus type 2. Zdorovja nacii. 2019; 57(4): 82-84. ISSN 2077-6594.

Дата надходження рукопису до редакції: 02.03.2020 p.

Goal of research: to study the level of awareness of patients undergoing sanatorium-and-spa treatment about metabolic syndrome, methods of its prevention by means of lifestyle changes and the role of nurses in patients' training on metabolic syndrome prevention. 
Materials and methods. 100 patients who were undergoing treatment at the Ružbachy Cherry Resort were anonymously interviewed with the use of the original questionnaire. The issue of the questionnaire consisted of a block of questions on the metabolic syndrome and block of issues relating to the lifestyle of the respondents.

Results. When creating the design of the study, 7 hypotheses were set which were verified through a questionnaire. 100 patients were interviewed, including 49 males and 51 women. The average age of respondents was 40 years. When processing data from the questionnaire, we found that $56 \%$ of respondents said they could not calculate their body mass index. According to our findings, most respondents are overweight or obese and unable to determine whether they have overweight or obese. It can be noted for sure that according to the answers received, patients with higher education pay more attention to physical training and sports, both active and entertaining. Patients with higher education are more likely to eat healthy foods compared to patients with other education levels. Women eat healthier compared to men, their diet is more diverse. It consists of more fruits and vegetables compared to men's diets, in which, on the contrary, meat dishes dominate. More than half of the respondents are ready to receive information on the metabolic syndrome from educational lectures or training materials. In the work we specify the importance of nursing in the prevention of this serious civilization disease and the indispensable role of nurses in training the patients.

Conclusions. Education is one of the non-pharmacological ways of influencing the patient and his family in the context of secondary prophylaxis and is an important part of the patient's overall treatment. This is a process that affects their behavior. This allows us to make changes in the knowledge, relationships and skills necessary to strengthen, protect and develop the health of patients. This is an important part of all nursing activities.

Key words: metabolic syndrome, diseases of civilization, education, prevention, nursing.

Мета дослідження: вивчити рівень інформованості пацієнтів, що проходять санаторно-курортне лікування про метаболічний синдром, методи його профілактики за допомогою зміни способу життя і ролі медсестер в навчанні пацієнтів з питань попередження метаболічного синдрому.

Матеріали та методи. 3 використанням оригінальної анкети анонімно опитано 100 пацієнтів, які проходили лікування на курорті Вишні Ружбахи. Питання анкети складалися з блоку питань по метаболічному синдрому і блоку питань, що стосуються способу життя респондентів.

Результати. При створенні дизайну дослідження було сформульовано 7 гіпотез, які проходили перевірку за допомогою анкети. Всього опитано 100 пацієнтів, з них 49 чоловіків і 51 жінка. Середній вік респондентів склав 40 років. При обробці даних з анкети ми з'ясували, що 56\% респондентів заявили, що не можуть розрахувати свій індекс маси тіла. Згідно $з$ нашими результатами, більшість респондентів мають надлишкову вагу або страждають ожирінням і не в змозі визначитит самі, чи мають вони надлишкову вагу або ожиріння. Можна 3 упевненістю сказати, що згідно 3 отриманими відповідями, пацієнти 3 вищою освітою приділяють більше уваги занять фізкультурою і спортом, як активними, так і розважальними. Пацієнти з вищою освітою частіше їдять здорову їжу в порівнянні 3 пацієнтами 3 іншими рівнями освіти. Жінки харчуються здоровіше чоловіків, їх раціон харчування більш різноманітний. Він складається з більшої кількості овочів і фруктів в порівнянні з чоловічими дієтами, в яких, навпаки, переважають м'ясні страви. Більше половини респондентів готові отримувати інформацію по метаболічному синдрому за допомогою навчальних лекцій або навчальних матеріалів. У роботі ми вказуємо на важливість сестринської справи в профілактиці цього серйозного цивілізаційного захворювання і на незамінну роль медсестри в навчанні пацієнтів.

Висновки. Освіта являє собою один з нефармакологічних способів впливу на пацієнта і його сім'ю в контексті вторинної профілактики і $є$ важливою частиною загального лікування пацієнта. Це процес, який впливає на їх поведінку. Це дозволяє нам вносити зміни в знання, відносини і навички, необхідні для зміцнення, захисту і розвитку здоров'я пацієнтів. Це важлива частина всієї сестринської діяльності.

Ключові слова: метаболічний синдром, цивілізаційні захворювання, навчання, профілактика, сестринська справа.

Цель исследования: изучить уровень информированости пациентов, проходящих санаторно-курортное лечение о метаболическом синдроме, методах его профилактики посредством изменения образа жизни и роли медсестер в обучении пациентов по вопросам предупреждения метаболического синдрома.

Материал и методы. С использованние оригинальной анкеты анонимно опрошено 100 пациентов, которые проходили лечение на курорте Вышне Ружбахи. Вопросы анкеты состояли из блока вопросов о метаболическом синдроме и блока вопросов, касающиеся их образа жизни респондентов.

Результаты. При создании дизайна исследования было сформулировано 7 гипотез, которые проходили проверку с помощью анкеты. Всего опрошено 100 пациентов, из них 49 мужчин и 51 женщина. Середний возраст респондентов составил 40 лет. При обработке данных из анкеты мы выяснили, что 56\% респондентов заявили, что не могут рассчитать свой индекс массы тела. Согласно нашим результатам, большинство респондентов имеют избыточный вес или страдают ожирением и не в состоянии судить сами, имеют ли они избыточный вес или ожирение. Можно с уверенностью сказать, что согласно полученным ответам, пациенты с высшим образованием уделяют больше внимания занятиям физкультурой и спортом, как активными, так и развлекательными. Пациенты с высшим образованием чаще едят здоровую пищу по сравнению с пациентами с другими уровнями образования. Женщины питаются здоровее мужчин, их рацион питания более разнообразен. Он состоит из большего количества овощей и фруктов по сравнению с 
мужскими диетами, в которых, наоборот, мы можем чаще употреблять мясные блюда. Более половины респондентов готовы получать информацию о метаболическом синдроме с помощью учебных лекций или учебных материалов. В работе мы указываем на важность сестринского дела в профилактике этого серьезного цивилизационного заболевания и на незаменимую роль медсестры в обучении пациентов.

Выводы. Образование представляет собой один из нефармакологических способов воздействия на пациента и его семьи в контексте вторичной профилактики и является важной частью общего лечения пациента. Это процесс, который влияет на их поведение. Это позволяет нам вносить изменения в знания, отношения и навыки, необходимые для укрепления, защиты и развития здоровья пациентов. Это важная часть всей сестринской деятельности.

Ключевые слова: метаболический синдром, цивилизационные заболевания, обучение, профилактика, сестринское дело.

Конфлікт інтересів: відсутній.

Conflicts of interest: authors have no conflicts of interest to declare.

\section{Відомості про авторів}

Bc. Petreková Veronika - student; St. Elizabeth University of Health and Social Sciences, Bratislava, n. o. Institute of Social Sciences and Health Care of the blessed P.P. Gojdič and V. Hopko, Spišská Nová Ves - Prešov.

veronikape76@centrum.sk.

Belovičová Mária - assoc. Prof., MD. PhD, St. Elizabeth University of Health and Social Sciences, Bratislava - teacher; Field office in Michalovce a Prešov; Internal Clinic for Liver Disease Diagnosis and Treatment, Remedium s.r.o. Bardejov Spa, Slovakia. mriab9@gmail.com. 